\title{
REMEDIASI MISKONSEPSI SISWA MENGGUNAKAN STRATEGI KONFLIK KOGNITIF BERBANTUAN SIMULASI PHET TENTANG RANGKAIAN LISTRIK DI SMA
}

\author{
Yusran, Edy Tandililing, Hamdani \\ Program Studi Pendidikan Fisika FKIP Untan Pontianak \\ Email: yusran46@student.untan.ac.id
}

\begin{abstract}
This research aimed to determine the effectiveness of cognitive conflict strategy assisted by PhET Simulation to remediate students' misconception on DC electric circuits. A total 35 students were selected from class XI IPA 1 SMAN 1 Teluk Keramat by using intact group random sampling technique. The research design in this study using one group pretestposttest design. Data was collected by using the diagnostic tests in the form of multiplechoice with open reasoning comprised of 18 questions by representing three concepts related to DC electric circuits. The result shows that average of decrease in number of students' who have misconceptions for each concepts were $53,33 \%$ with a significance of decrease by McNemar test is $\chi_{\text {calculate }}^{2}(47,27)>\chi_{\text {table }}^{2}(3,84)$. Therefore, it can be conclude that the decrease in number of students' who have misconception before and after remediation is significant. The effectiveness of remediation by using cognitive conflict strategy assisted by PhET Simulation is 0.67 (medium). This research is expected to be used as reference for teachers to remediate students' misconception.
\end{abstract}

Keywords: Remediation, Conflict Cognitive, PhET Simulation

Pembelajaran fisika di SMA saat ini mengalami beberapa permasalahan. Salah satu permasalahan yang dihadapi siswa adalah sulitnya memahami pelajaran fisika (Samudra, Suastra, \& Suma, 2014). Dampak dari permasalahan ini menyebabkan hasil belajar siswa masih rendah dan belum dapat memenuhi standar keberhasilan pembelajaran fisika. Selain itu, hal tersebut dapat dilihat dari laporan Trend in International Mathematics and Science Study (TIMSS) tahun 2015 yang menunjukkan dalam bidang Ilmu Pengetahuan Alam (IPA), Indonesia berada diperingkat 44 dari 47 negara yang berpatisipasi (Martin, Mullis, Foy, \& Hooper, 2016). Hasil belajar matematika dan IPA termasuk fisika yang masih rendah ini mungkin salah satu penyebabnya adalah miskonsepsi yang dialami siswa.

Mursalin (2013) mengartikan miskonsepsi atau salah konsep sebagai kesalahan pemahaman dalam menghubungkan suatu konsep dengan konsep-konsep yang lain, antara konsep yang baru dengan konsep yang lama yang sudah ada dalam pikiran siswa. Miskonsepsi dipandang sebagai pengertian yang tidak akurat akan konsep, penggunaan konsep yang salah, klasifikasi contoh-contoh yang salah, kekacauan konsep-konsep yang berbeda dan hubungan hirarkis konsep-konsep yang tidak benar (Suparno, 2013).

Sampai saat ini banyak siswa yang mengalami miskonsepsi dalam bidang fisika. Wandersee, Mintzes dan Novak (dalam Suparno, 2013: 11) menyatakan bahwa terjadi miskonsepsi dalam semua bidang fisika. Diantaranya dari 700 studi mengenai miskonsepsi dalam bidang fisika, ada 300 miskonsepsi tentang mekanika; 159 tentang listrik; 70 tentang panas, optika, dan sifat-sifat materi; 35 tentang bumi dan antariksa; serta 10 studi mengenai fisika modern. Listrik dinamis merupakan salah satu cabang kelistrikan yang dipelajari di SMA. Materi listrik dinamis sangat penting dipelajari karena menjadi landasan 
untuk mempelajari elektronika dan berkaitan erat dengan kehidupan sehari-hari. Selain itu, jika materi ini tidak dipelajari dengan benar maka kemungkinan besar akan menimbulkan kesulitan pada jenjang yang lebih tinggi.

Salah satu bagian kajian materi listrik dinamis adalah rangkaian listrik. Siswa terkadang mengalami kesulitan dalam memahami konsep-konsep kelistrikan terutama pada terutama rangkaian listrik karena materinya cenderung abstrak dan kebanyakan guru menerapkan metode pembelajaran konvensional dalam mengajarkan listrik dinamis (Hamdani, 2013). Kesulitan siswa untuk memahami suatu konsep dapat menimbulkan terjadinya miskonsepsi (Mursalin, 2013).

Beberapa hasil penelitian tentang miskonsepsi siswa pada rangkaian listrik yang telah berhasil diungkap antara lain: (1) siswa menganggap arus listrik di dalam rangkaian seri sebagian diserap pada setiap komponen rangkaian sehingga menurut siswa arus dekat kutub positif lebih besar dari pada arus dekat kutub negatif sumber daya (Purba \& Depari, 2008); (2) siswa menggap nyala lampu dan arus listrik akan bertambah jika salah satu lampu pada rangkaian paralel dicabut (Mursalin, 2013; Hamdani, 2013); (3) siswa beranggapan komponen yang diubah hanya mempengaruhi arus dalam komponen sesudahnya dan tidak mempengaruhi arus dalam komponen sebelumnya (Purba \& Depari, 2008; Hamdani, 2013).

Berbagai upaya telah dirumuskan untuk mencegah dan memperbaiki miskonsepsi. Suparno (2013: 55) merumuskan, "langkahlangkah mengatasi miskonsepsi sebagai berikut: (1) mencari atau mengungkapkan miskonsepsi yang dilakukan siswa, (2) menemukan penyebab miskonsepsi tersebut, (3) mencari perlakuan yang sesuai untuk mengatasi miskonsepsi tersebut." Karena sudah tersedia miskonsepsi siswa tentang rangkaian listrik arus searah, maka salah satu solusi untuk mengatasi miskonsepsi tersebut adalah dengan memberikan remediasi berupa pembelajaran ulang dengan menggunakan strategi konflik kognitif. Remediasi adalah kegiatan pembelajaran yang diarahkan untuk mengatasi kesulitan belajar siswa dengan cara mengubah, memperbaiki atau memperjelas kerangka berpikirnya (Tampubolon, 2001).

Menurut Dreyfus yang dikutip Wiradana (2012) menyatakan "strategi konflik kognitif merupakan strategi pengubah konseptual dalam upaya mengubah miskonsepsi-miskonsepsi siswa menuju konsep yang benar". Strategi konflik kognitif dikembangkan dari pandangan Piaget tentang teori Konstruktivisme. Menurut Ma'rifah (2012), "teori tersebut mengatakan bahwa siswa harus membangun pengetahuannya sendiri dari pengalaman baru. Perubahan konsep merupakan bagian dari mekanisme belajar yang dibutuhkan siswa untuk membangun pengetahuan tentang peristiwa atau prinsip sampai terstruktur kembali". Konflik kognitif merupakan faktor yang penting dalam perubahan konsep (Kang, dkk, 2010). Konflik kognitif dapat dihasilkan oleh situasi ketidakseimbangan berupa ketidakpuasan yang diakibatkan oleh pertentangan antara apa yang dilihat (informasi baru) dengan apa yang dimiliki dalam struktur kognitifnya (Ma'rifah, 2012).

Santyasa (2007) menyatakan bahwa dalam kondisi konflik kognitif siswa dihadapkan pada tiga pilihan, yaitu: (1) mempertahankan intuisinya semula, (2) merevisi sebagian intuisinya melalui proses asimilasi, dan (3) merubah pandangannya yang bersifat intuisi tersebut dan mengakomodasikan pengetahuan baru. Perubahan konsep terjadi ketika siswa memutuskan pada pilihan yang ketiga. Agar terjadi proses perubahan konsep, belajar melibatkan pembangkitan dan restrukturisasi konsepsi-konsepsi yang dibawa oleh siswa sebelum pembelajaran (Brook \& Brook, 1993 dalam Santyasa, 2007).

Baser (2006) meneliti tentang pembelajaran berbasis strategi konflik kognitif untuk mengubah konsepsi siswa tentang konsep suhu dan kalor, hasilnya menunjukkan bahwa skor rata-rata post-test siswa di kelas eksperimen lebih tinggi dari kelas kontrol pada akhir pembelajaran tentang pemahaman konsep suhu dan kalor. Hasil penelitian Resmiyati (2014) menyimpulkan bahwa strategi konflik kognitif dapat meningkatkan pemahaman konsep dan menurunkan miskonsepsi siswa. Selain itu, Madu \& Orji (2015) menyimpulkan pengajaran konflik kognitif lebih efektif dalam memperbaiki 
miskonsepsi dibandingkan pembelajaran konvensional.

Selain strategi pembelajaran, media pembelajaran sangat berpengaruh dalam meningkatkan pemahaman konsep siswa dan meminimalkan miskonsepsi siswa (Suhandi, dkk, 2009). Salah satu media yang dapat digunakan untuk mengatasi miskonsepsi siswa adalah simulasi PhET (Andriani, 2015). Simulasi PhET menekankan hubungan antara fenomena nyata dengan bidang ilmu yang mendasari, mendukung pendekatan interaktif dan konstruktivis, memberikan umpan balik, dan menyediakan ruang kerja untuk berkreasi (Perkins, dkk, 2006).

Simulasi Physics Education of Technology $(\mathrm{PhET})$ merupakan media belajar yang dikembangkan oleh Universitas Colorado dalam bentuk simulasi interaktif dan virtual laboratory. Media simulasi PhET dapat menjadi salah satu alternatif dalam menjelaskan konsep rangkaian listrik. Andriani (2015) menyatakan bahwa simulasi PhET membutuhkan keterlibatan/interaksi siswa, membuat pembelajaran lebih menarik, dan mampu memvisualisasikan konsep fisika dalam bentuk model. Selain itu, simulasi PhET membuat siswa memiliki pola berpikir konstruktivisme, dengan menggabungkan pengetahuan awal dan temuan-temuan virtual dari simulasi yang dijalankan.

Suparno (2013: 105), menyatakan "Bila dalam simulasi siswa menemukan data yang sangat berbeda dengan yang mereka pikirkan sebelumnya, maka siswa akan mengalami konflik dalam pikirannya. Konflik inilah yang memacu mereka bertanya mengapa demikian. Hasil simulasi yang berlawanan dengan gagasan awal siswa akhirnya akan menghasilkan perubahan konsep dalam diri siswa." Dengan pertentangan konsepsi ini dapat menyebabkan adanya ketidakpuasan pada siswa terhadap konsepsi yang dimilikinya sehingga memungkinkan terjadinya perubahan konsep yang kuat pada siswa yang sesuai dengan konsepsi ilmiah (Marwiah, 2014).

Penelitian Mursalin (2013) menyimpulkan model simulasi PhET berbantuan lembar kerja dapat digunakan untuk meremediasi dan meminimalkan miskonsepsi siswa. Taşlıdere
(2013) meneliti pembelajaran berorientasi perubahan konsep disertai lembar kerja konsep kartun dan simulasi komputer hasilnya efektif dalam meningkatkan pemahaman dan menurunkan miskonsepsi siswa pada rangkaian listrik arus searah. Peneliti yang lain juga menyimpulkan bahwa kelas eksperimen yang menggunakan pembelajaran berbantuan simulasi komputer lebih baik dari kelas kontrol yang menggunakan pembelajaran konvensional (Bayrak, 2008; Hursen \& Asiksoy, 2015).

Berdasarkan hasil pra-riset di SMA Negeri 1 Teluk Keramat, hasil belajar siswa pada materi listrik dinamis masih belum mencapai kriteria ketuntasan minimal (KKM). Sebanyak 97\% dari 35 siswa kelas XB tidak mencapai KKM pada ulangan harian. Hal ini menunjukkan bahwa siswa masih mengalami kesulitan dan miskonsepsi dalam memahami materi listrik dinamis.

Tujuan dari penelitian ini adalah untuk menentukan efektivitas remediasi miskonsepsi siswa menggunakan strategi konflik kognitif berbantuan simulasi PhET pada materi rangkaian listrik arus searah di SMA Negeri 1 Teluk Keramat.

\section{METODE}

Penelitian ini berbentuk pre-experimental design rancangan one-group pretest-posttest design. Rancangan penelitian ini ditunjukkan pada Tabel 1.

Tabel 1. One Group Pretest-Posttest Design

\begin{tabular}{ccc}
\hline Pre-test & Treatment & Post-test \\
\hline $\mathrm{O}_{1}$ & $\mathrm{X}$ & $\mathbf{O}_{2}$ \\
\hline & \multicolumn{2}{c}{ (Sugiyono, 2013: 11) }
\end{tabular}

Populasi penelitian ini adalah seluruh siswa kelas XI IPA SMA Negeri 1 Teluk Keramat tahun pelajaran 2016/2017 berjumlah 73 siswa yang terdiri dari dua kelas, yaitu kelas XI IPA 1 dan kelas XI IPA 2. Kelas XI IPA $1(N=36)$ terpilih sebagai sampel penelitian melalui teknik intact group random sampling.

Tes diagnostik yang digunakan pada penelitian ini terdiri dari 18 soal dengan alasan terbuka. Soal tersebut terdiri dari 9 soal pre-test dan 9 soal post-test yang bersifat paralel. Setiap soal memiliki satu pilihan jawaban betul, dua distraktor, dan satu kolom untuk menuliskan 
alasan. Selain itu, karena penggunaan tes bertujuan untuk mengidentifikasi miskonsepsi dan melihat pemahaman konsep siswa, semua soal bersifat konseptual dan tidak memerlukan perhitungan kuantitatif dalam menjawab pertanyaannya.

Tes diagnostik tersebut terbagi dalam tiga indikator, yaitu: 1) Menjelaskan konsep arus listrik dalam rangkaian seri (Indikator I);2) Menjelaskan pengaruh perubahan nilai hambatan terhadap kuat arus pada rangkaian seri (Indikator II); 3) Menjelaskan pengaruh dicabutnya salah satu lampu dari dua lampu identik yang dirangkai paralel terhadap kuat arus yang mengalir (Indikator III). Setiap indikator diwakili tiga nomor soal yang bersifat ekivalen. Data jawaban siswa tiap indikator kemudian dievaluasi berdasarkan konsistensi jawaban siswa untuk mengolongkan siswa tersebut mengalami miskonsepsi atau tidak miskonsepsi.

Prosedur dalam penelitian ini terdiri dari tiga tahap,yaitu: 1) Tahap persiapan, 2) tahap pelaksanaan, 3) tahap akhir.

\section{Tahap Persiapan}

Langkah-langkah yang dilakukan pada tahap persiapan antara lain: (1) Melakukan studi literatur; (2) Melakukan observasi ke SMA Negeri 1 Teluk Keramat; (3) Merumuskan masalah penelitian; (4) Menyiapkan perangkat pembelajaran berupa rencana pelaksanaan pembelajaran remediasi dan LKS; (5) Membuat instrumen penelitian berupa soal pre-test dan post-test; (6) Melakukan validasi dan revisi instrumen; (7) Mengajukan permohonan surat riset dan surat tugas ke FKIP Untan; (8) Melakukan observasi untuk menentukan sampel dan waktu perlakuan dilaksanakan; (9) Menguji coba soal penelitian ke SMA Negeri 2 Teluk
Keramat; (10) Menghitung reliabilitas instrumen penelitian.

\section{Tahap Pelaksanaan}

Tahap pelaksanaan terdiri dari: (1) Memberikan pre-test dalam bentuk soal pilihan ganda dengan tiga alternatif pilihan dan reasoning terbuka dengan tujuan untuk mengetahui jumlah siswa yang mengalami miskonsepsi sebelum dilakukan remediasi; (2) Melaksanakan kegiatan remediasi berupa pengajaran ulang menggunakan strategi konflik kognitif berbantuan simulasi PhET pada materi rangkaian listrik arus searah; (3) Memberikan post-test dalam bentuk soal pilihan ganda dengan tiga alternatif pilihan dan reasoning terbuka bertujuan untuk mengetahui penurunan jumlah siswa yang mengalami miskonsepsi.

\section{Tahap Akhir}

Tahap akhir terdiri dari: (1) Menganalisis data yang diperoleh dari pre-test dan post-test; (2) mendeskripsikan hasil analisis data dan menarik kesimpulan sebagai jawaban dari rumusan masalah; 3) Menyusun laporan penelitian.

\section{HASIL DAN PEMBAHASAN}

Penelitian ini dilaksanakan pada salah satu kelas XI IPA di SMA Negeri 1 Teluk Keramat. Melalui teknik pengambilan sampel yang digunakan, maka kelas XI IPA 1 sebagai kelas sampel. Sampel penelitian berjumlah 36 orang siswa tetapi data yang diolah sebanyak 35 siswa karena satu orang siswa tidak mengikuti kegiatan post-test.

Hasil analisis jawaban siswa pada pre-test dan post-test secara ringkas dapat dilihat pada Tabel 2.

Tabel 2. Distribusi Jumlah Siswa yang Mengalami Miskonsepsi

\begin{tabular}{|c|c|c|c|c|c|c|c|c|}
\hline \multirow[b]{2}{*}{ Indikator } & \multicolumn{4}{|c|}{ Pre-test } & \multicolumn{4}{|c|}{ Post-test } \\
\hline & $\begin{array}{c}\text { No } \\
\text { soal }\end{array}$ & $\sum_{\text {Salah }}$ & $\sum_{\mathbf{M i s}}$ & $\begin{array}{c}\% \\
\text { Mis }\end{array}$ & $\begin{array}{c}\text { No } \\
\text { soal }\end{array}$ & $\sum_{\text {Salah }}$ & $\sum_{\text {Mis }}$ & $\begin{array}{c}\% \\
\text { Mis }\end{array}$ \\
\hline \multirow{3}{*}{ Indikator I } & 1 & 19 & \multirow{3}{*}{24} & \multirow{3}{*}{$68,57 \%$} & 4 & 10 & \multirow{3}{*}{6} & \multirow{3}{*}{$17,14 \%$} \\
\hline & 2 & 26 & & & 8 & 3 & & \\
\hline & 9 & 29 & & & 3 & 7 & & \\
\hline \multirow{3}{*}{ Indikator II } & 3 & 25 & \multirow{3}{*}{28} & \multirow{3}{*}{$80,00 \%$} & 5 & 10 & \multirow{3}{*}{13} & \multirow{3}{*}{$37,14 \%$} \\
\hline & 4 & 26 & & & 6 & 19 & & \\
\hline & 5 & 23 & & & 7 & 13 & & \\
\hline
\end{tabular}




\begin{tabular}{|c|c|c|c|c|c|c|c|c|}
\hline \multirow[b]{2}{*}{ Indikator } & \multicolumn{4}{|c|}{ Pre-test } & \multicolumn{4}{|c|}{ Post-test } \\
\hline & $\begin{array}{c}\text { No } \\
\text { soal }\end{array}$ & $\sum_{\text {Salah }}$ & $\sum_{\text {Mis }}$ & $\begin{array}{c}\% \\
\text { Mis }\end{array}$ & $\begin{array}{c}\text { No } \\
\text { soal }\end{array}$ & $\sum_{\text {Salah }}$ & $\sum_{\text {Mis }}$ & $\begin{array}{c}\% \\
\text { Mis }\end{array}$ \\
\hline \multirow{4}{*}{ Indikator III } & 6 & 32 & \multirow{3}{*}{32} & \multirow{3}{*}{$91,43 \%$} & 1 & 9 & \multirow{3}{*}{9} & \multirow{3}{*}{$25,71 \%$} \\
\hline & 7 & 30 & & & 2 & 12 & & \\
\hline & 8 & 30 & & & 9 & 22 & & \\
\hline & & & a-rata & $80,00 \%$ & & & a-rata & $26,67 \%$ \\
\hline
\end{tabular}

Berdasarkan Tabel 2 dapat diketahui bahwa sebelum pembelajaran remediasi seluruh konsep yang diujikan pada konsep rangkaian arus lisrik searah mengalami miskonsepsi. Pada Indikator I yaitu konsep arus listrik dalam rangkaian seri ada 24 orang siswa $(68,57 \%)$ mengalami miskonsepsi. Pada Indikator II yaitu menjelaskan pengaruh perubahan nilai hambatan terhadap kuat arus pada rangkaian seri ada 28 orang siswa $(80,00 \%)$ mengalami miskonsepsi. Sedangkan untuk Indikator III yaitu menjelaskan pengaruh dicabutnya salah satu lampu dari dua lampu indentik yang dirangkai paralel ada 32 $(91,43 \%)$ siswa mengalami miskonsepsi. Rerata persentase jumlah siswa yang miskonsepsi pada tiga indikator tersebut mencapai $80,00 \%$. Setelah diberikan pembelajaran remediasi dengan strategi konflik kognitif berbantuan simulasi PhET terjadi penurunan jumlah siswa yang miskonsepsi pada tiap indikator. Persentase penurunan pada Indikator I sebesar $17,14 \%$. Selanjutnya persentase penurunan persentase pada Indikator II sebesar 37,14\%. Sedangkan pada Indikator III persentase penurunan jumlah siswa yang miskonsepsi sebesar $25,71 \%$. Rerata persentase jumlah siswa yang miskonsepsi turun menjadi 26,67\%. Dengan kata lain, terdapat selisih persentase jumlah siswa yang miskonsepsi sebesar 53,33\% antara sebelum dan sesudah diberikan remediasi.

Berdasarkan analisis jawaban siswa pada soal tes diagnostik ditemukan beberapa siswa memiliki konsepsi yang berbeda dalam memahami rangkaian listrik arus searah. Konsepsi yang berbeda tersebut ditemukan disemua indikator yang diujikan. Deskripsi bentuk-bentuk konsepsi siswa pada tiap indikator disajikan pada Tabel 3.

Tabel 3. Profil Miskonsepsi Siswa

\begin{tabular}{|c|c|c|c|c|c|}
\hline \multirow{2}{*}{ Indikator } & \multirow{2}{*}{ Bentuk Konsepsi } & \multicolumn{2}{|c|}{ Pre-test } & \multicolumn{2}{|c|}{ Post-test } \\
\hline & & $\mathbf{n}$ & $\%$ & $\mathbf{n}$ & $\%$ \\
\hline \multirow{4}{*}{ Indikator I } & $\begin{array}{l}\text { Miskonsepsi } \\
\text { Arus listrik di dekat kutub positif baterai lebih } \\
\text { besar dari pada arus listrik yang ada didekat kutub } \\
\text { negatif baterai sehingga lampu yang di dekat kutub } \\
\text { positif menyala lebih terang dari pada lampu yang } \\
\text { didekat kutub negatif baterai. }\end{array}$ & 17 & $48,57 \%$ & 4 & $11,43 \%$ \\
\hline & $\begin{array}{l}\text { Miskonsepsi } \\
\text { Arus mengalir dari kutub negatif menuju kutub } \\
\text { positif sehingga lampu yang di dekat kutub negatif } \\
\text { lebih terang dari pada lampu yang lainnya. }\end{array}$ & 6 & $17,14 \%$ & 2 & $5,71 \%$ \\
\hline & $\begin{array}{l}\text { Miskonsepsi } \\
\text { Terangnya lampu dan kuat arus listrik pada } \\
\text { rangkaian seri dipengaruhi posisi lampu dari } \\
\text { sumber tegangan. }\end{array}$ & 1 & $2,86 \%$ & 0 & $0,00 \%$ \\
\hline & $\begin{array}{l}\text { Konsepsi Ilmiah } \\
\text { Lampu menyala sama terang dan kuat arus yang } \\
\text { mengalir di setiap titik (lampu) pada rangkaian seri } \\
\text { sama besar. }\end{array}$ & 11 & $31,43 \%$ & 29 & $82,86 \%$ \\
\hline
\end{tabular}




\begin{tabular}{|c|c|c|c|c|c|}
\hline \multirow{2}{*}{ Indikator } & \multirow{2}{*}{ Bentuk Konsepsi } & \multicolumn{2}{|c|}{ Pre-test } & \multicolumn{2}{|c|}{ Post-test } \\
\hline & & $\mathbf{n}$ & $\%$ & $\mathbf{n}$ & $\%$ \\
\hline \multirow{9}{*}{ Indikator II } & Miskonsepsi & & & & \\
\hline & $\begin{array}{l}\text { Perubahan nilai hambatan hanya mempengaruhi } \\
\text { arus listrik dalam lampu sesudah hambatan dan } \\
\text { tidak mempengaruhi arus listrik dalam lampu } \\
\text { sebelum hambatan. }\end{array}$ & 15 & $42,86 \%$ & 13 & $37,14 \%$ \\
\hline & Miskonsepsi & & & & \\
\hline & $\begin{array}{l}\text { Arus yang didekat kutub positif baterai lebih besar } \\
\text { daripada arus yang didekat kutub negatif baterai. }\end{array}$ & 4 & $11,43 \%$ & 0 & $0,00 \%$ \\
\hline & Miskonsepsi & & & & \\
\hline & $\begin{array}{l}\text { Perubahan nilai hambatan hanya mempengaruhi } \\
\text { komponen sebelum hambatan dan tidak } \\
\text { mempengaruhi komponen sesudahnya }\end{array}$ & 7 & $20,00 \%$ & 0 & $0,00 \%$ \\
\hline & $\begin{array}{l}\text { Miskonsepsi } \\
\text { Sebagian arus listrik diserap oleh hambatan, } \\
\text { sehingga lampu yang berada sesudah hambatan } \\
\text { meredup dan arus pada lampu tersebut berkurang. }\end{array}$ & 2 & $5,71 \%$ & 0 & $0,00 \%$ \\
\hline & Konsepsi Ilmiah & & & & \\
\hline & $\begin{array}{l}\text { Hambatan yang diubah nilainya mempengaruhi } \\
\text { arus dalam seluruh rangkaian berubah besarnya. }\end{array}$ & 7 & $20,00 \%$ & 22 & $62,86 \%$ \\
\hline \multirow{4}{*}{$\begin{array}{l}\text { Indikator } \\
\text { III }\end{array}$} & $\begin{array}{l}\text { Miskonsepsi } \\
\text { lampu yang lain bertambah terang dan arus listrik } \\
\text { yang mengalir ke lampu lainnya akan bertambah } \\
\text { besar jika salah salah satu lampu dilepas dari dua } \\
\text { lampu identik dirangkai paralel. }\end{array}$ & 29 & $88,57 \%$ & 9 & $25,71 \%$ \\
\hline & $\begin{array}{l}\text { Miskonsepsi } \\
\text { Arus listrik akan tetap mengalir pada } \\
\text { cabang/lampu yang telah dilepas/dicabut. }\end{array}$ & 1 & $2,86 \%$ & 0 & $0 \%$ \\
\hline & $\begin{array}{l}\text { Miskonsepsi } \\
\text { Jika salah satu lampu dicabut, lampu yang lainnya } \\
\text { akan padam. }\end{array}$ & 2 & $5,71 \%$ & 0 & $0 \%$ \\
\hline & $\begin{array}{l}\text { Konsepsi Ilmiah } \\
\text { Nyala lampu tetap dan arus listrik yang mengalir } \\
\text { pada suatu cabang rangkaian paralel nilainya tidak } \\
\text { berubah jika pada rangkaian ditambah atau } \\
\text { dikurang cabang paralel yang nilai hambatannya } \\
\text { sama }\end{array}$ & 3 & $8,57 \%$ & 26 & $74,29 \%$ \\
\hline
\end{tabular}

Ada 13 bentuk konsepsi yang ditemukan pada jawaban siswa dalam penelitian ini seperti yang disajikan pada Tabel 3. Konsepsi siswa tersebut terdiri dari tiga konsepsi ilmiah dan sepuluh lainnya tergolong miskonsepsi. Bentuk konsepsi paling beragam ditemukan pada indikator II dengan jumlah lima bentuk konsepsi, sedangkan indikator I dan III masing-masing dengan jumlah empat bentuk konsepsi.
Analisis statistik yang dilakukan menggunakan uji McNemar untuk taraf signifikansi 0,05 diperoleh harga $\chi^{2}{ }_{\text {hitung }}$ $(47,27)$ lebih besar dari $\chi_{\text {tabel }}^{2}(3,84)$. Hasil uji McNemar ini menunjukkan bahwa terdapat penurunan jumlah siswa yang miskonsepsi secara signifikan pada materi rangkaian listrik arus searah setelah diberikan kegiatan remediasi 
menggunakan strategi konflik kognitif berbantuan simulasi PhET.

Harga proporsi penurunan jumlah siswa yang mengalami miskonsepsi setelah diremediasi menggunakan strategi konflik kognitif berbantuan simulasi PhET didapatkan rata-rata harga proporsi sebesar 0,67 dan dikategorikan sedang. Hasil ini menunjukkan bahwa strategi konflik kognitif berbantuan simulasi PhET efektif dalam menurunkan miskonsepsi yang dialami siswa kelas pada materi rangkaian listrik arus searah.

\section{Pembahasan}

Temuan-temuan dalam penelitian ini mengindikasikan siswa mengalami miskonsepsi pada materi rangkai listrik arus searah. Terlihat dari hasil pre-test dalam penelitian ini rata-rata pesentase sebesar $80 \%$ jumlah siswa mengalami miskonsepsi. Hal ini menunjukkan kemampuan siswa dalam memahami konsep masih tergolong rendah. Kemungkinan penyebab miskonsepsi siswa diduga karena reasoning yang tidak lengkap dan intuisi yang salah serta konsepsi awal siswa itu sendiri.

Berdasarkan hasil penelitian ditemukan ada 13 bentuk konsepsi siswa pada materi rangkaian listrik arus searah. Dari 13 bentuk konsepsi tersebut, tiga bentuk konsepsi siswa digolongkan ke dalam kategori konsepsi yang ilmiah atau konsep yang sesuai dengan ilmuwan, sedangkan sepuluh bentuk konsepsi siswa tergolong miskonsepsi. Secara keseluruhan setiap Indikator ditemukan lebih dari satu bentuk konsepsi siswa. Kemungkinan hal tersebut terjadi karena materi rangkaian listrik arus searah tergolong abstrak yang sukar untuk diamati secara langsung sehingga menimbulkan banyak penafsiran ketika siswa mempelajarinya.

Indikator I menjelaskan tentang arus listrik dalam rangkaian seri. Total jumlah siswa yang mengalami miskonsepsi pada Indikator I tersebut sebesar 68,57\% (Tabel 2). Bentuk miskonsepsi yang paling dominan dilakukan siswa sebelum diberikan remediasi adalah siswa menganggap arus listrik di dekat kutub positif baterai lebih besar dari pada arus listrik yang ada didekat kutub negatif baterai sehingga lampu yang di dekat kutub positif menyala lebih terang dari pada lampu yang didekat kutub negatif baterai sebesar $48,57 \%$ (Tabel 3). Temuan ini sesuai dengan hasil penelitian sebelumnya yang diungkapkan Andriani (2015), Purba dan Depari (2008) lampu yang disusun seri akan lebih terang jika diletakkan di dekat kutub positif baterai, karena lampu yang dekat dengan kutub positif baterai akan dilalui arus listrik lebih dulu dan arusnya lebih besar. Miskonsepsi ini diduga terjadi karena reasoning atau penalaran yang tidak lengkap/keliru yang timbul akibat dari informasi yang dimiliki siswa tidak lengkap sehingga mengakibatkan siswa menarik kesimpulan yang keliru.

Miskonsepsi lain yang ditemukan yaitu terangnya lampu dan kuat arus listrik pada rangkaian seri dipengaruhi posisi lampu dari sumber tegangan (lampu yang dekat dengan sumber tegangan lebih terang; Arus mengalir dari kutub negatif menuju kutub positif sehingga lampu yang di dekat kutub negatif lebih terang dari pada lampu yang lainnya.

Selanjutnya pada Indikator II tentang menjelaskan pengaruh perubahan nilai hambatan terhadap kuat arus pada rangkaian seri, persentase jumlah siswa mengalami miskonsepsi sebesar $80 \%$ (Tabel 2). Siswa banyak yang menganggap bahwa hambatan yang diubah hanya mempengaruhi arus listrik dalam lampu sesudah hambatan dan tidak mempengaruhi arus listrik dalam lampu sebelum hambatan sebanyak 42,86\% (Tabel 3). Menurut Dardjito dan Berg (1991) penalaran siswa seperti ini disebut local reasoning (pengaruh perubahan rangkaian hanya lokasi saja) atau sequential reasoning' (komponen yang terletak sebelum yang diubah tidak kena perubahan).

Bentuk miskonsepsi lain yang ditemukan adalah siswa menganggap bahwa arus yang didekat kutub positif baterai lebih besar daripada arus yang didekat kutub negatif baterai, perubahann nilai hambatan hanya mempengaruhi komponen (lampu) sebelum hambatan dan tidak mempengaruhi komponen (lampu) sesudahnya. Miskonsepsi seperti ini diduga dapat terjadi akibat intuisi yang salah. Siswa secara spontan menyatakan gagasannya berdasarkan perasaan dalam diri mereka tanpa berpikir secara objektif dan rasional.

Sebagian siswa lain menganggap bahwa sebagian arus listrik diserap oleh hambatan, sehingga lampu sesudah hambatan meredup dan 
arus pada lampu tersebut berkurang. Diduga miskonsepsi ini terjadi akibat penalaran siswa yang tidak lengkap dan kemungkinan adanya pemikiran humanistik.

Terakhir pada Indikator III yaitu menjelaskan pengaruh dicabutnya salah satu lampu dari dua lampu identik yang dirangkai paralel. Siswa yang mengalami miskonsepsi pada indikator ini sebesar 91,42\% (Tabel 2). Mayoritas siswa yang mengalami miskonsepsi menganggap bahwa nyala lampu yang lain bertambah terang dan arus listrik yang mengalir ke lampu lainnya akan bertambah besar jika salah salah satu lampu dicabut dari 2 lampu identik dirangkai paralel. Temuan ini sejalan dengan hasil penelitian Purba dan Depari (2008), Mursalin (2013). Kemungkinan penyebab mengapa siswa beranggapan demikian karena pengetahuan logika matematika siswa yang menyebutkan bahwa menurut hukum I Kirchhoff yang semula arus listrik terbagi ke lampu-1 dan lampu-2, tetapi setelah salah satu lampu dicabut otomatis akan menambah besar arus listrik yang melalui lampu yang lainnya. Dengan kata lain, siswa tidak memperhitungkan hambatan lampu sehingga terjadi kesalahan konsep (Mursalin, 2013).

Bentuk miskonsepsi yang lainya adalah siswa menganggap arus listrik akan tetap mengalir pada cabang/lampu yang telah dilepas/dicabut; dan jika salah satu lampu dicabut, lampu yang lainnya akan padam. Miskonsepsi ini diduga terjadi karena penalaran siswa yang tidak lengkap dan instuisi yang salah. Selain itu kemampuan siswa juga mempunyai pengaruh pada miskonsepsi siswa (Suparno: 40).

Penelitian ini telah mengungkapkan bentuk-bentuk miskonsepsi siswa pada materi rangkaian listrik arus searah, tetapi penyebab miskonsepsi masih belum digali lebih jauh. Penjelasan tentang penyebab miskonsepsi yang disajikan dalam pembahasan ini berupa kemungkinan-kemungkinan yang berdasarkan pada teori para ahli dan kesimpulan oleh peneliti sendiri yang perlu diselidiki lebih lanjut lagi.

Berdasarkan data hasil pre-test dan post-test terlihat bahwa terjadi penurunan jumlah siswa yang mengalami miskonsepsi tiap indikator dengan persentase yang bervariasi. Penurunan jumlah siswa yang miskonsepsi terbesar $65,71 \%$ terjadi pada Indikator III dan disusul oleh Indikator I sebesar 54,29\%. Sedangkan penurunan yang paling kecil $(42,86 \%)$ terjadi pada Indikator II. Beberapa siswa yang mengalami miskonsepsi pada saat pre-test mampu menjawab dengan benar pada saat posttest. Hasil analisis menunjukkan remediasi dengan menggunakan strategi konflik kognitif berbantuan simulasi PhET dapat menurunkan jumlah siswa yang mengalami miskonsepsi ratarata sebesar 53,33\%. Masih adanya siswa yang mengalami miskonsepsi setelah diberikan kegiatan remediasi diduga terjadi akibat adanya siswa yang kurang fokus dan minat belajar siswa yang rendah dalam menyimak materi yang disampaikan oleh peneliti. Hal ini sependapat dengan Suparno (2013: 42) siswa tidak memahami konsep setelah dilakukan pembelajaran dikarenakan minat siswa yang rendah.

Penurunan rata-rata persentase jumlah siswa yang mengalami miskonsepsi siswa yang relatif besar dapat terjadi karena melalui strategi konflik kognitif siswa mampu membangun sendiri konsep yang sesuai dengan konsep ilmuwan. Berdasarkan strategi konflik kognitif, siswa bekerja melalui diskusi dalam kelompok dengan teman-temannya dan juga diskusi dengan guru. Siswa akan mengekspresikan gagasannya di dalam kelompok. Melalui interaksi dengan teman-temannya akan memperkaya perkembangan intelektual individu. Sehingga timbul konflik konseptual dalam dirinya. Dengan demikian siswa akan lebih terbuka pada perubahan berikutnya. Hal ini diperkuat dengan penjelasan Suparno (2013: 99) yang menyatakan bahwa saat siswa mengungkapkan gagasannya dan dikritik oleh teman lain, dia akan merasa tidak puas dengan gagasannya sendiri, dan mulai timbul konflik konseptual dalam dirinya. Dengan pengalaman ini siswa akan lebih terbuka pada perubahan berikutnya. Menurut Mosik \& Maulana (2010) menyebutkan bahwa struktur kognitif siswa yang mengalami reorganisasi untuk menyesuaikan dengan informasi yang baru diterimanya (akomodasi). Dengan akomodasi siswa mengubah konsep-konsep pokok mereka yang lama karena tidak cocok lagi dengan persoalan yang baru. Harapannya adalah agar 
siswa melakukan reorganisasi struktur kognitif sehingga terjadi perubahan konseptual dari konsepsi yang salah menuju konsepsi yang benar.

Penurunan jumlah siswa yang mengalami miskonsepsi dimulai dari fase confrontation kemudian dikuatkan pada fase accomodation. Pada fase confrontation terjadi proses pelunturan keyakinan konsepsi awal siswa sehingga terjadi disekuilibrium pada pemikiran siswa yang sering dikenal dengan konflik kognitif. Dengan lunturnya keyakinan tersebut, maka akan memudahkan dalam rekonstruksi konsepsi di benak siswa. Rekonstruksi konsepsi baru terjadi pada fase accomodation dan penguatan konsepsi baru.

Terjadinya penurunan jumlah siswa yang miskonsepsi menandai terjadi perubahan dari konsepsi yang keliru menjadi konsepsi yang benar yang sesuai dengan konsepsi para ahli atau ilmuwan. Perubahan konsepsi ini tidak lepas dari peran media demonstrasi berupa simulasi PhET yang digunakan pada strategi konflik kognitif.

Sebagai contoh pada awalnya cukup banyak siswa yang memiliki konsepsi bahwa arus listrik di dekat kutub positif baterai lebih besar dari pada arus listrik yang ada didekat kutub negatif baterai sehingga lampu yang di dekat kutub positif menyala lebih terang dari pada lampu yang didekat kutub negatif baterai. Konsepsi ini adalah termasuk miskonsepsi. Konsepsi siswa mulai goyah (luntur) setelah mereka dihadapkan pada demonstrasi simulasi PhET seperti yang sesungguhnya.

Mereka melihat dengan mata kepala mereka sendiri yaitu arus listrik yang mengalir pada setiap lampu dalam rangkaian seri sama besar baik yang dekat kutub positif maupun yang didekat kutub negatif sumber daya (baterai). Keadaan ini tentu membuat pikiran mereka menjadi ragu, terjadi konflik dipikirannya, dan mulai bertanya-tanya jangan-jangan konsepsi yang selama ini dianutnya keliru. Konsepsi ini jelas bertentangan dengan konsepsi awal siswa sehingga muncul konflik kognitif. Keadaan seperti ini akan menguntungkan ketika guru ingin merekonstruksi konsepsi siswa yang keliru tersebut menjadi konsepsi yang benar (Hikmat, dkk, 2014). Siswa yang mengalami konflik kognitif tersebut secara perlahan mengganti konsepsi awal yang bertentangan dengan menerima konsepsi baru yang sesuai dengan konsepsi ilmuwan. Untuk penguatan siswa diberi penjelasan oleh peneliti tentang konsep yang dibahas.

Beberapa siswa yang masih mengalami miskonsepsi setelah proses remediasi kemungkinan diakibatkan siswa tersebut cenderung mempertahankan konsepsi awal yang mereka miliki karena mereka tidak memperhatikan demonstrasi dengan serius dan juga ada pengaruh variabel dari luar yang tidak dapat dikendalikan. Selain itu miskonsepsi yang terjadi pada siswa bersifat resisten sehingga mengubah miskonsepsi bukanlah hal yang mudah. Hasil ini didukung dengan pernyataan dari Suparno (2013: 93) konsep yang bertentangan dengan teori atau konsep awal siswa tidak selalu diterima.

Signifikansi yang paling besar artinya jumlah siswa yang pada pre-test miskonsepsi kemudian pada post-test menjadi tidak miskonsepsi $(-\mathrm{ke}+)$ jauh lebih besar jika dibandingkan siswa yang pada pre-test tidak miskonsepsi kemudian pada post-test menjadi miskonsepsi ( $+\mathrm{ke}-)$. Berdasarkan hasil, Indikator III tentang pengaruh dicabutnya salah satu lampu pada rangkaian paralel merupakan yang paling signifikan, terlihat dari perubahan jumlah siswa yang miskonsepsi adalah yang tertinggi. Untuk indikator I tentang konsep arus listrik dalam rangkaian seri, signifikasinya diurutan kedua setelah indikator III. Signifikansi perubahan jumlah siswa yang miskonsepsi paling rendah yaitu pada Indikator II tentang menjelaskan pengaruh perubahan nilai hambatan terhadap kuat arus pada rangkaian seri. Perubahan jumlah siswa dari yang miskonsepsi menjadi tidak miskonsepsi diakibatkan terjadinya proses asimilasi dan akomodasi pada siswa.

Secara keseluruhan terjadi penurunan jumlah siswa yang miskonsepsi yang signifikan antara pre-test dan post-test, terlihat dari harga $\chi_{\text {hitung }}^{2}(47,27)$ lebih besar dari $\chi_{\text {tabel }}^{2}(3,84)$. Ini berarti telah terjadi penurunan yang signifikan jumlah siswa yang miskonsepsi sesudah diberikan kegiatan remediasi menggunakan strategi konflik kognitif berbantuan simulasi PhET. 
Ada beberapa penelitian sebelumnya yang telah menyelidiki tentang strategi konflik kognitif dan simulasi PhET yang dapat dijadikan pembanding, meskipun sesungguhnya terdapat perbedaan antara penelitian-penelitian tersebut. Penelitian ini menyelidiki tentang penggunaan strategi konflik kognitif berbantuan simulasi PhET untuk mengubah miskonsepsi menjadi konsepsi ilmiah. Pengaruh penggunaan strategi konflik kognitif terhadap pemahaman konsep siswa sebelumnya telah diteliti oleh Baser (2006). Hasil penelitiannya menunjukkan bahwa skor rata-rata post-test siswa di kelas eksperimen secara signifikan lebih tinggi daripada kelas kontrol. Meidahrianti, Zulherman dan Taufiq (2014) dalam penelitiannya juga menyimpulkan bahwa bahwa pembelajaran dengan menggunakan strategi konflik kognitif (cognitive conflict) dapat mempengaruhi perubahan konseptual siswa. N-gain yang didapat setelah penelitian yaitu sebesar 0,75 dengan kriteria tinggi. Hal ini menunjukkan bahwa peningkatan pemahaman konseptual siswa sangat baik.

Penelitian Mursalin (2013) menyimpulkan model simulasi PhET berbantuan lembar kerja dapat digunakan untuk meremediasi dan meminimalkan miskonsepsi siswa. Selain itu, penelitian Rizal (2015) tentang remediasi miskonsepsi dalam membaca grafik pada materi gerak lurus dengan media animasi PhET menemukan bahwa penggunaan simulasi PhET dapat menurunkan jumlah siswa yang miskonsepsi sebesar 52,22\% dengan signifikansi penurunan berdasarkan Uji McNemar yaitu $\chi_{\text {hitung }}^{2}(10,675)$ lebih besar dari $\chi^{2}{ }_{\text {tabel }}$ $(3,84)$. Dapat disimpulkan bahwa penelitianpenelitian terdahulu mengkonfirmasi bahwa strategi konflik kognitif berbantuan simulasi PhET yang digunakan dalam penelitian ini dapat meremediasi dan meminimalkan miskonsepsi siswa pada materi rangkaian listrik arus searah.

Hasil temuan menunjukkan bahwa strategi konflik kognitif berbantuan simulasi PhET dapat mengurangi jumlah siswa yang mengalami miskonsepsi. Remediasi menggunakan strategi konflik kognitif berbantuan simulasi PhET di kelas XI IPA 1 SMA Negeri 1 Teluk Keramat memberikan tingkat efektivitas dengan rata-rata harga proporsi penurunan jumlah siswa yang mengalami miskonsepsi pada materi rangkaian listrik arus searah sebesar 0,67 dengan kategori sedang menurut diagram "Barometer John Hattie". Maka dari itu, dapat disimpulkan bahwa penggunaan konflik kognitif berbantuan simulasi PhET dapat dikatakan efektif dalam meremediasi miskonsepsi siswa pada materi rangkaian listrik arus searah.

Temuan ini sejalan dengan beberapa penelitian tentang penggunaan strategi konflik kognitif dan simulasi PhET sebelumnya pernah dilakukan. Hasil penelitian Ma'rifah, Sumarni, dan Siadi (2012) menunjukkan bahwa keefektifan reduksi miskonsepsi peserta didik mencapai $86,67 \%$ dan pereduksian miskonsepsi per item soal mencapai $70,00 \%$. Madu \& Orji (2015) menyimpulkan pengajaran konflik kognitif lebih efektif dalam memperbaiki miskonsepsi dibandingkan pembelajaran konvensional. McKagan dkk (2008) menemukan bahwa penggunaan animasi PhET sangat efektif membantu siswa dalam memahami konsep yang sifatnya abstrak pada fisika kuantum. Hursen dan Asiksoy (2015) dalam penelitianya menemukan bahwa metode pengajaran berbantuan simulasi lebih efektif daripada metode pengajaran tradisional. Selain itu, penelitian Taslidere (2013) menyimpulkan bahwa pembelajaran dengan simulasi dan $1 \mathrm{ks}$ konsep kartun efektif untuk pemahaman dan dapat menurunkan miskonsepsi siswa pada materi rangkaian arus listri searah. Efektivitas simulasi PhET yang disertakan dalam model pembelajaran langsung (direct intruction) ditemukan tergolong sedang dengan tingkat efektivitas sebesar 0,45 (Luthfiah, 2013) dan 0,56 (Qosim, 2016).

Strategi konflik kognitif bisa digunakan untuk memperbaiki miskonsepsi karena pada setiap fase memiliki kerangka dan tujuan yang jelas untuk meremediasi miskonsepsi. Pada fase Diagnosis untuk mengidentifikasi miskonsepsi yang dialami siswa dengan mendeteksi prakonsepsi atau pengetahuan awal siswa. Untuk mengatasi miskonsepsi hal pertama yang penting dilakukan adalah membuat siswa sadar akan konsepsi awal mereka apakah benar atau keliru, dari konsep awal ini dapat dideteksi miskonsepsi (Suparno, 2013). 
Fase Clarification bertujuan siswa mengklarifikasi dan merivisi konsepsi awal mereka melalui diskusi dalam kelompok dengan teman-teman dan juga diskusi dengan guru. Hal ini diperkuat dengan penjelasan Suparno (2013: 99) yang menyatakan bahwa saat siswa mengungkapkan gagasannya dan dikritik oleh teman lain, dia akan merasa tidak puas dengan gagasannya sendiri, dan mulai timbul konflik konseptual dalam dirinya.

Fase Confrontation menciptakan konflik kognitif dalam pikiran siswa. Dalam proses perubahan konsep yang keliru menjadi benar memerlukan prinsip konflik kognitif dalam pikiran seseorang melalui peristiwa anomali berupa fakta yang tidak sesuai dengan dugaan atau konsepsi awalnya (Suparno, 2013). Peristiwa anomali dihadirkan melalui demonstrasi simulasi PhET yang dilakukan oleh peneliti sendiri. Ketika informasi baru berbeda dengan konsepsi siswa maka akan terjadi konflik pikiran dalam diri siswa tersebut sehingga memingkinkan terjadinya perubahan konsep.

Pada fase Accomodation ini dilakukan untuk memperkuat dan meyakinkan siswa untuk mengubah konsepsi mereka yang keliru siswa diharapkan bisa menerima konsep baru dan mengubah mikonsepsinya (Liang, 2016). Guru membantu siswa agar merefleksikan diri dan melihat perbedaan konsepsi awal siswa dan konsepsi baru. Guru membantu siswa agar pelan-pelan melakukan perubahan atas konsep awalnya (Suparno, 2013: 101).

Dikarenakan bentuk penelitian ini merupakan pre-experimental design, maka masih banyak faktor yang tidak dapat dikontrol selama pelaksanaan penelitian. Meskipun telah dilakukan remediasi, namun masih ada siswa yang mengalami miskonsepsi. Hal ini bukan semata-mata efektivitas dari strategi konflik kognitif berbantun simulasi PhET itu sendiri, melainkan kemampuan peneliti dalam menciptakan suatu pembelajaran yang menggabungkan strategi konflik kognitif, metode diskusi, demonstrasi, dan media simulasi PhET yang bertujuan untuk memperbaiki miskonsepsi siswa menjadi konsepsi yang sesuai dengan ilmuwan. Penyebab lainnya yang mungkin adalah media yang digunakan dalam tahap akomodasi konsep kurang variatif, atau aktivitas yang dilakukan sesuai dengan tipe kecerdasan yang nereka miliki.

\section{SIMPULAN DAN SARAN \\ Simpulan}

Berdasarkan hasil penelitian dan pembahasan dapat disimpulkan, mayoritas siswa pada pre-test menganggap lampu bertambah terang dan arus listrik yang mengalir ke lampu lainnya akan bertambah besar jika salah salah satu lampu dilepas dari dua lampu identik dirangkai paralel. Sedangkan pada post-test mayoritas siwa menganggap perubahan nilai hambatan hanya mempengaruhi arus listrik dalam lampu sesudah hambatan dan tidak mempengaruhi arus listrik dalam lampu sebelum hambatan. Penurunan jumlah siswa yang mengalami miskonsepsi setelah diberikan remediasi rata-rata sebesar 53,33\%. Perhitungan uji McNemar menunjukkan terjadi penurunan yang signifikan jumlah siswa yang miskonsepsi pada keseluruhan konsep dengan harga $\chi^{2}$ hitung $(47,27)>\chi_{\text {tabel }}^{2}(3,84)$. Efektivitas strategi konflik kognitif berbantuan simulasi PhET dalam meremediasi miskonsepsi siswa pada materi rangkaian listrik arus searah tergolong sedang yaitu 0,67 .

\section{Saran}

Penelitian selanjutnya disarankan sebagai berikut: (1) untuk pembuatan Lembar Kerja Siswa berisi panduan menggunakan media simulasi Physics Education Technology (PhET) agar lebih dikembangkan semudah dan seefektif mungkin bagi siswa dalam proses remediasi; (2) siswa sendiri ataupun berpasangan mencoba melakukan simulasi PhET berupa virtual lab dan dibimbing baik oleh guru maupun peneliti, dengan pertimbangan ada dukungan sarana komputer di sekolah tempat penelitian. Hal ini dilakukan untuk mempermudah pemahaman siswa tentang konsep yang disampaikan serta dapat meningkatkan antusiasme dan motivasi siswa dalam kegiatan pembelajaran.

\section{DAFTAR RUJUKAN}

Andriani, E. 2015. Remedi Miskonsepsi Beberapa Konsep Listrik Dinamis pada Siswa SMA Melalui Simulasi PheT Disertai 
LKS. Jurnal Pendidikan Fisika. 3 (4): 362369.

Baser, M. 2006. Fostering Conceptual Change By Cognitive Conflict Based Instruction on Students Understanding of Heat and Temperature Concepts. Eurasia Journal of Mathematics, Science and Technology Education. 2 (2):96-114.

Bayrak, C. 2008. Effect of Computer Simulations Program on University Students' Achievments In Physics. Turkish Online Journal of Distance Education. 9 (4): 53-62.

Berg, E. V. D. 1991. Miskonsepsi Fisika dan Remediasi. Universitas Kristen Satya Wacana. Salatiga

Hamdani. 2013. Deskripsi Miskonsepsi Siswa Tentang Konsep-Konsep dalam Rangkaian Listrik. Jurnal Pendidikan Matematika dan IPA. 4 (1): 1-12.

Hikmat. Tayubi, Y. R., Purwana, U. \& Suhandi, A. 2014. Strategi Konflik Kognitif Berbantuan Media Simulasi Virtual Dalam Pembelajaran Fisika Berorientasi Pengubahan Konseptual untuk Meningkatkan Pemahaman Konsep dan Menurunkan Kuantitas Siswa yang Miskonsepsi. Prosiding Pertemuan Ilmiah XXVIII HFI Jateng \& DIY. 26 April 2014, Yogyakarta, Indonesia. Hal. 342-347.

Hursen, C. \& Asiksoy, G. 2015. The Effect of Simulation Methods in Teaching Physics on Students' Academic Success. World Journal on Educational Technology. 7 (1): 87-98.

Kang, H., Scharmann, L. C., Kang, S. \& Noh, T. 2010. Cognitive Conflict and Situational Interest as Factors Enfluencing Conceptual Change. International Journal of Environmental \& Science Education. 5 (4): 383-405.
Liang, S. 2016. Teaching the Concept of Limit by Using Conceptual Conflict Strategy and Desmos Graphing Calculator. International Journal of Research in Education and Science. 2 (1): 35-48.

Luthfiah, E. 2013. Penerapan Pembelajaran Langsung Berbantuan Media Physics Education Technology (PhET) Simulation untuk Remediasi Miskonsepsi Siswa Kelas IX MTS Rasau Jaya tentang Rangkaian Listrik Arus Searah. Skripsi. FKIP Universitas Tanjungpura, Pontianak.

Madu, B. C. \& Orji, E. 2015. Effects of Cognitive Conflict Instructional Strategy on Students' Conceptual Change in Temperature and Heat. SAGE Open. 5 (3): 1-9. DOI: $10.1177 / 2158244015594662$.

Ma'rifah, Sumarni, W. \& Siadi, K. 2012. Keefektifan Pereduksian Miskonsepsi Melalui Strategi Konflik Kognitif Pada Pemahaman Konseptual dan Algoritmik. Chemistry in Education. 2 (1): 42-48.

Martin, M. O., Mullis, I. V. S., Foy, P. \& Hooper, M. 2016. TIMSS 2015 International Results in Science. http://timssandpirls.bc.edu/ timss2015/international-results. Diakses tanggal 6 Februari 2017.

Marwiah, 2014. Penggunaan Conceptual Change Model Berbantuan Media Simulasi Virtual untuk Menurunkan Kuantitas Siswa yang Miskonsepsi dan Meningkatkan Pemahaman Konsep Siswa SMK pada Materi Fluida Statis. Tesis. Universitas Pendidikan Indonesia, Bandung.

McKagan, S. B. et al. 2008. Developing and Researching PhET simulations for Teaching Quantum Mechanics. American Journal of Physics. 76 (4): 406-417.

Meidahrianti., Zulherman., \& Taufiq, 2014. Pengaruh Strategi Pembelajaran Konflik Kognitif Terhadap Perubahan Konseptual Siswa pada Materi Listrik Dinamis Di SMA 
Negeri 1 Tanjung Batu. Jurnal Inovasi dan Pembelajaran Fisika. 1 (1): 48-55.

Mosik \& Maulana, P. 2010. Usaha Mengurangi Terjadinya Miskonsepsi Fisika Melalui Pembelajaran dengan Pendekatan Konflik Kognitif. Jurnal Pendidikan Fisika Indonesia 6. 98-103.

Mursalin. 2013. Model Remediasi Miskonsepsi Materi Rangkaian Listrik dengan Pendekatan Simulasi PhET. Jurnal Pendidikan Fisika Indonesia. (9): 1-7.

Perkins, K. et al., 2006. PhET: Interactive Simulations for Teaching and Learning Physics. The Physics Teacher. 44. 18-23.

Purba, J. P. \& Depari, G. 2008. Penelusuran Miskonsepsi Mahasiswa tentang Konsep dalam Rangkaian Listrik Menggunakan Certainty of Response Index dan Interview. http://file.upi.edu/Direktori/FPTK/JUR._P END._TEKNIK_ELEKTRO/194710251980 O21JANULIS_P_PURBA/Makalah_Semina r/miskonsepsi_(Invotec).pdf. Diakses Maret 2016.

Qosim, H. 2016. Remediasi Miskonsepsi Siswa Dengan Model Pembelajaran Direct Instruction Berbantuan Animasi PhET pada Materi Fluida Statis Di SMA Negeri 7 Pontianak. Skripsi. FKIP Universitas Tanjungpura, Pontianak.

Resmiyati, E. 2014. Penerapan Strategi Konflik Kognitif Pada Model Pembelajaran Berorientasi Perubahan Konseptual untuk Meningkatkan Pemahaman Konsep dan Menurunkan Miskonsepsi Siswa SMP. Skripsi. Univesitas Pendidikan Indonesia, Bandung.

Rizal, A. K. 2015. Remediasi Miskonsepsi Membaca Grafik Gerak Lurus Dengan Physics Education Technology (PhET). Jurnal Pendidikan dan Pembelajaran. 4 (9): $1-12$
Samudra, G. B., Suastra, I. W., \& Suma, K. 2014. Permasalahan-Permasalahan yang Dihadapi Siswa SMA di Kota Singaraja dalam Mempelajari Fisika. Jurnal Pendidikan IPA. 4(1).

Santyasa, I. W. 2007. Model-Model Pembelajaran Inovatif. Pelatihan tentang Penelitian Tindakan Kelas bagi Guru-Guru SMP dan SMA. 29 Juni - 1 Juli 2007, Nusa Penida, Indonesia. Hal. 1-16.

Sugiyono. 2013. Metode Penelitian Pendidikan. ALFABETA. Bandung.

Suhandi, A., Sinaga, P., Kaniawati, I. \& Suhendi, E. 2009. Efektivitas Penggunaan Media Simulasi Virtual pada Pendekatan Pembelajaran Konseptual Interaktif dalam Meningkatkan Pemahaman Konsep dan Meminimalkan Miskonsepsi. Jurnal Pengajaran MIPA. 13 (1): 35-47.

Suparno, P. 2013. Miskonsepsi \& Perubahan Konsep Dalam Pendidikan Fisika. PT Gramedia Widiasarana Indonesia. Jakarta.

Tampubolon, T. 2001. Meningkatkan Hasil Belajar Gelombang Kelas II B Cawu II SLTP N 13 Medan Melalui Pembelajaran Fisika Model Konstruktivis. Jurnal Pendidikan Science. 25 (1): 30-39.

Taşlıdere, E. 2013. Effect of Conceptual Change Oriented Instruction on Students' Conceptual Understanding and Decreasing Their Misconceptions in DC Electric Circuits. Creative Education. 4 (4): 273282.

Wiradana, I. W. G. 2012. Pengaruh Strategi Konflik Kognitif dan Berpikir Kritis Terhadap Prestasi Belajar IPA Kelas VII SMP Negeri 1 Nusa Penida. Jurnal Penelitian. 2 (2): 1-19. 